\title{
Die Arthrodese des oberen Sprunggelenks über den sog. transfibularen Zugang
}

\section{The Transfibular Approach for Ankle Arthrodesis}

\author{
Gerhard Flückiger, Martin Weber ${ }^{1}$
}

\section{Zusammenfassung \\ Operationsziel}

Knöcherne Verbindung zwischen Tibia und Talus in neutraler Fußstellung zur Wiederherstellung einer schmerzfreien Belastbarkeit der Gliedmaße.

\section{Indikationen}

Weitgehender Knorpelverlust am oberen Sprunggelenk mit schmerzhafter, stark eingeschränkter Beweglichkeit mit oder ohne gleichzeitige Fehlstellung.

Teilnekrosen des Talusdoms oder der Tibiaepiphyse. Neuroarthropathie (sog. Charcot-Arthropathie) mit progredienter Gelenkfehlstellung.

Revisionsoperation nach fehlgeschlagener Implantation einer Sprunggelenkprothese.

\section{Kontraindikationen}

Akute eitrige Gelenkinfektion. Vollständige Talusnekrose.

\section{Operationstechnik}

Dorsolateraler Zugang zur distalen Fibula. Schonen des periostalen Gefäßplexus. Fibulaosteotomie von proximal-lateral nach distal-medial. Durchtrennen des vorderen Syndesmosenbandes sowie der Ligamenta fibulotibiale anterius und fibulocalcaneare. Durchtrennen des hinteren Syndesmosenbandes. Plane Resektion der Talusund Tibiagelenkflächen. Anfrischen des Innenknöchels, Resektion der Innenknöchelspitze von einem medialen Zugang. Reposition des Talus senkrecht unter die Tibia unter Berücksichtigung von Rückfußvalgus und Außenrotation. Temporäre Fixation mit Kirschner-Drähten. Nach Röntgenkontrolle in zwei Ebenen definitive Fixation mit zwei bis drei Zugschrauben. Resektion der medialen Fibulakortikalis, Anfrischen der Incisura fibulae. Einpassen des distalen Fibulafragments an die laterale Kontur von Tibia und Talus; Fixation mit Kortikalisschrauben an Tibia und Talus.

\author{
Abstract \\ Objective \\ Bony fusion between tibia and talus in neutral position of \\ foot. Return to a pain-free function of the lower limb.
}

\section{Indications}

Extensive loss of articular cartilage accompanied by a painful and considerably limited motion with or without malalignment.

Partial avascular necrosis of talar dome or distal tibial epiphysis.

Neuroarthropathy (Charcot joint) with progressive malalignment of ankle.

Revision surgery after failed total ankle arthroplasty.

\section{Contraindications}

Acute purulent joint infection.

Total avascular necrosis of talus.

\section{Surgical Technique}

Posterolateral approach to the distal fibula taking care to preserve the periosteal vessels. Fibular osteotomy from proximal lateral to distal medial. Division of the anterior tibiofibular, anterior fibulotibial, and fibulocalcaneal ligaments. Division of posterior tibiofibular ligament. Transverse planar resection of tibial and talar articular surfaces. Freshening of the medial malleolus. Resection of the tip of medial malleolus through a medial incision. Positioning of talus perpendicular to the tibia, paying attention to the valgus of the hindfoot and external rotation. Temporary fixation with Kirschner wires. Radiographic control in two planes followed by fixation with two or three lag screws. Removal of the medial fibular cortex, freshening of the lateral gutter, and fixation of the distal fibular fragments to tibia and talus with cortical screws.

\section{DOI 10.1007/s00064-005-1148-9}

'Universitätsklinik für Orthopädische Chirurgie, Inselspital Bern, Schweiz. 


\section{Ergebnisse}

19 Patienten mit 20 Arthrodesen konnten 12-69 Monate (Durchschnitt 39 Monate) postoperativ nachuntersucht werden. Sämtliche Arthrodesen waren konsolidiert. Bei einem Patienten Pseudarthrose der Fibula. 19 Arthrodesen in korrekter Stellung, einmal Spitzfußstellung von $3^{\circ}$. Durchschnittlicher Rückfußscore der AOFAS (American Orthopedic Foot and Ankle Society): 78,5 Punkte (40-86 Punkte). Sämtliche Patienten gaben postoperativ deutlich weniger Schmerzen als präoperativ und eine zufriedenstellende Funktion an. Alle würden sich erneut operieren lassen.

\section{Schlüsselwörter Oberes Sprunggelenk · OSG-Arthrose · OSG- Arthrodese $\cdot$ Transfibularer Zugang}

\section{Vorbemerkungen}

Obwohl in den letzten Jahren ermutigende kurz- und mittelfristige Ergebnisse implantierter Prothesen des oberen Sprunggelenks (OSG) publiziert worden sind $[3,6,13,17,18,24]$, bleibt die OSG-Arthrodese bei jungen und aktiven Patienten mit hohen Belastungsansprüchen, bei Patienten mit rheumatischen Erkrankungen und vor allem bei Patienten mit groben Fehlstellungen im Sprunggelenk die Therapie der Wahl [5, $8,10,23,25,26]$.

Seit der Erstbeschreibung einer derartigen Arthrodese durch E. Albert 1882 (zitiert in [20]) sind über 30 verschiedene Techniken propagiert worden. Ein transfibularer Zugang wird erstmals 1908 von Goldthwait [12] erwähnt. Gatellier [11] und Allredge [2] publizierten ihre Varianten mit Herunterklappen des Außenknöchels, gestielt an den Außenbändern. Horwitz [15] beließ die Fibula dorsal weichteilgestielt und klappte sie am Ende des Eingriffs zurück, nachdem er die mediale Kortikalis des Außenknöchels und die Incisura fibulae der Tibia sowie die laterale Taluswange angefrischt hatte; er fixierte das Fibulafragment mit transossären Nähten. Adams [1] berichtete 1948 über seine guten Erfahrungen mit vollständiger Exzision der distalen Fibula. Nach der Arthrodese tibiotalar replantierte er die angefrischte Fibula und fixierte sie mit drei Schrauben an Tibia und Talus. Auch die vollständige Exzision des Außenknöchels ohne Replantation wird als Zugang zur OSG-Arthrodese erfolgreich praktiziert und als transfibularer Zugang bezeichnet [19].

Das Konzept der Kompressionsarthrodese am oberen Sprunggelenk führte Charnley [7] 1951 ein; es kann

\section{Results}

20 arthrodeses in 19 patients were followed up for an average of 39 months (12-69 months). All arthrodeses were fused. In one patient a fibular pseudarthrosis was encountered. All arthrodeses healed in a correct position but one that consolidated with a pes equinus of $3^{\circ}$. The average AOFAS (American Orthopedic Foot and Ankle Society) hindfoot score reached 78.5 points (40-86 points). A marked reduction of symptoms and satisfactory function were reported postoperatively by all patients. All would be willing to undergo surgery again.

\section{Key Words \\ Ankle · Ankle osteoarthritis · Ankle arthrodesis . Transfibular approach}

\section{Introductory Remarks}

In spite of the fact that, recently, encouraging shortand medium-term results of total ankle arthroplasties have been reported [3, 6, 13, 17, 18, 24], the ankle arthrodesis remains the treatment of choice for young and active patients with high demands, for rheumatoid patients, and for patients with a marked malalignment of the ankle $[5,8,10,23,25,26]$.

Since the original description of an ankle arthrodesis by E. Albert in 1882 (cited by [20]), more than 30 different techniques have been published. In 1908, Goldthwait [12] was the first to recommend a transfibular approach. Gatellier [11] and Allredge [2] modified this approach by turning the fibula distally leaving it attached to the lateral ligaments. Horwitz [15] left the posterior soft tissues attached to the fibula and turned the distal fragment posteriorly. Following the arthrodesis, resection of the medial fibular cortex, and freshening of the fibular gutter, he replaced the fibular fragment and fixed it with transosseous sutures. In 1948, Adams [1] reported good results with an enucleation of the distal fibula. After ankle arthrodesis he fixed the freshened distal fibular fragment to tibia and talus with three screws. Another successful approach to ankle arthrodesis consisted of the complete excision of the lateral malleolus without reimplantation and was termed transfibular approach [19].

The concept of compression arthrodesis of the ankle was introduced by Charnley [7] in 1951. It considerably reduced the incidence of nonunion and is now accepted worldwide as a standard technique. The fixation with external tensioners used by Charnley has the advantage of being applicable in instances of poor 
heute weltweit als Standard gelten und trug wesentlich zur Verringerung von Pseudarthrosen bei. Die von Charnley verwendete Fixation mit äußerem Spanner besitzt den Vorteil, dass sie auch bei kritischen Weichteilverhältnissen und akutem Infekt angewandt werden kann. Nachteilig sind die aufwendige Pflege der Eintrittsstellen der Fixateurschrauben, die Behinderung der Mobilisation durch das Gestänge sowie die häufigen Infekte und Lockerungen der Schanz-Schrauben (18-80\%, zitiert in [4]). In neueren Arbeiten ergibt die Schraubenfixation eine gute Heilungsrate und eine geringe Anzahl von Komplikationen [9, 14, 20-22]. Neue arthroskopisch assistierte Techniken können mit noch weniger Komplikationen und einer guten Konsolidierungsrate gefallen [27], bedingen aber die Auswahl von Patienten ohne Fehlstellung. Die offenen Techniken besitzen den Vorteil, dass damit auch größere Fehlstellungen sicher korrigiert werden können.

Unser Operationskonzept besteht aus der Kompressionsarthrodese mit Schrauben in Verbindung mit dem transfibularen Zugang nach Horwitz [15]. Wir modifizierten die Technik insofern, als das gesamte laterale Periost und die dorsalen Weichteile an der distalen Fibula sorgfältig geschont und belassen werden, so dass die Fibula einen Teil ihrer Durchblutung behält. Nach der Refixation kann sie somit - biologisch gesehen - als vaskulär gestielter Knochenspan und - mechanisch gesehen - als laterale Überbrückungsplatte betrachtet werden. Der Zugang liegt zwischen den Versorgungsgebieten des Nervus suralis und des Nervus peroneus superficialis; er minimiert deswegen das Risiko einer intraoperativen Nervenverletzung und erlaubt eine exzellente Übersicht zur Korrektur von Deformitäten, insbesondere zur Rückverschiebung des häufig ventral subluxierten Talus.

\section{Operationsprinzip und -ziel}

Ein zerstörtes, schmerzhaftes, funktionseingeschränktes oder funktionsloses und evtl. fehlstehendes oberes Sprunggelenk wird durch Entfernen des Restknorpels, Anfrischen des subchondralen Knochens, Reposition und Kompression der großen spongiösen Knochenflächen stabil verblockt. Dadurch werden Schmerzfreiheit, Stabilität und Belastungsfähigkeit bei geringer Gehbehinderung erzielt. Die Fixation wird mit Kompressionsschrauben und lateral zusätzlich - mit dem überbrückenden distalen Fibulafragment erreicht. soft-tissue conditions and acute infections. The disadvantage is the time-consuming care of the entry points of the fixation screws, the interference of the rods with the gait, as well as the frequent infections and loosening of the Schanz screws (18-80\%, cited by [4]). More recent studies using screw fixation reported an encouraging rate of consolidation as well as a low number of complications [9, 14, 20-22]. With arthroscopically assisted techniques a further reduction in complications and improvement of the rate of consolidation can be expected [27]. However, this technique can only be done in the absence of malalignment. The advantage of open techniques lies in the possibility to correct major malalignments.

Our surgical principle rests on the arthrodesis with compression screws combined with the transfibular approach according to Horwitz [15]. We modified the technique, however, by preserving the entire lateral fibular periosteum and the posterior soft-tissue attachments to the distal fibula. This guarantees partial preservation of its blood supply. After refixation the distal fibula acts - in a biologic respect - as a pedicled bone graft and -in a mechanical respect - as a bridging plate. The approach lies between the areas supplied by the sural nerve and the superficial peroneal nerve. It therefore decreases the risk of intraoperative nerve injury while permitting an excellent assessment of the correction, in particular of the posterior positioning of the talus that is often subluxed anteriorly.

\section{Surgical Principles and Objective}

Stable fixation of a severely damaged, painful, and often malaligned ankle with reduced or absent function. After removal of the remaining articular cartilage, freshening of the subchondral bone, and reduction, the large cancellous bone surfaces are put under compression with screws. In addition, bridging of the arthrodesis laterally with the distal fibular fragment reinforces the fixation. This results in freedom of pain, stability, and full weight bearing while barely interfering with gait. 


\section{Vorteile}

- Verminderte Gefahr einer Nervenverletzung durch Eingehen zwischen dem Nervus suralis und dem lateralen Ast des Nervus peroneus superficialis.

- Der transfibulare Zugang ergibt eine sehr gute Übersicht.

- Problemloses Anfrischen des gesamten subchondralen Knochens.

- Korrekturen von großen Fehlstellungen sowie eine exakte Positionierung des Rückfußes sind unter Sichtkontrolle möglich.

- Einfache Platzierung der Kompressionsschrauben.

- Biologische und mechanische Verbesserung der tibiotalaren Fixation sowie kosmetische Verbesserung durch Aufschrauben des Fibulafragments.

- Ein sicherer Durchbau der Arthrodese ist zu erwarten.

\section{Nachteile}

- Bei Resektion von planen Knochenflächen resultiert eine Beinverkürzung von 7-10 mm.

- Aufwendige Präparation.

\section{Indikationen}

- Fortgeschrittene, symptomatische (schmerzhafte, bewegungseinschränkende) Arthrose des oberen Sprunggelenks (posttraumatisch, rheumatologisch, postinfektiös).

- Schmerzhafte Sprunggelenkarthrose jüngerer Patienten mit hohen Belastungen im Alltag.

- Ausgeprägte Fehlstellung im zerstörten Sprunggelenk nach Trauma, Infektion sowie bei Neuroarthropathie (sog. Charcot-Arthropathie).

- Teilnekrosen des Talusdoms oder der Tibiaepiphyse.

- Revisionsoperation nach fehlgeschlagener Implantation einer Sprunggelenkendoprothese.

\section{Kontraindikationen}

- Akuter eitriger Gelenkinfekt.

- Vollständige Talusnekrose.

- Fehlende Weichteildeckung.

- Eine Altersbegrenzung besteht nicht.

\section{Patientenaufklärung}

- Übliche Operationsrisiken wie Blutung, Thrombose, Embolie und Infektion sowie deren Prävention und Behandlung.

- Gefahr der Verletzung des Nervus suralis und des lateralen Asts des Nervus peroneus superficialis la-

\section{Advantages}

- Reduced risk of nerve injury given the approach between sural nerve and lateral branch of superficial peroneal nerve.

- The transfibular approach allows an excellent exposure.

- Easy freshening of the entire subchondral bone.

- Possibility of correction of major malalignments and exact positioning of hindfoot under direct vision.

- Easy placement of compressions screws.

- Biologic and mechanical enhancement of tibiotalar fixation as well as cosmetic advantage through screw fixation of fibular fragment.

- An uneventful bony consolidation can be expected.

\section{Disadvantages}

- The fashioning of flat surfaces leads to a shortening of the limb by $7-10 \mathrm{~mm}$.

- Time-consuming technique.

\section{Indications}

- Advanced and symptomatic (painful, decreased range of motion) osteoarthritis (secondary to trauma, rheumatoid arthritis, infection).

- Painful osteoarthritis in younger patients exposed to daily heavy demands.

- Marked malalignment of the damaged ankle secondary to trauma, infection as well as neuroarthropathy (Charcot joint).

- Partial avascular necrosis of talar dome or distal tibial epiphysis.

- Revision surgery after failed total ankle arthroplasty.

\section{Contraindications}

- Acute purulent ankle infection.

- Total avascular necrosis of talus.

- Absent soft-tissue coverage.

- There is no age limit.

\section{Patient Information}

- Usual surgical risks such as hemorrhage, thrombophlebitis, embolism, and infection.

- Explanation of preventive and therapeutic measures.

- Risk of injury to sural nerve, lateral branch of superficial peroneal nerve, tibial nerve, and medial malleolar branch of posterior tibial artery.

- Possible need for bone harvesting from iliac crest.

- Risk of nonunion, 7-12\% according to literature $[14,20]$. 
teral sowie des Nervus tibialis und der Arteria tibialis posterior medial.

- Verpflanzung eines Beckenkammspans kann erforderlich werden.

- Ausbildung einer Pseudarthrose in 7-12\% nach Literaturangaben $[14,20]$.

- Störende Schrauben können nach Durchbau der Arthrodese entfernt werden.

- Normales Gehen ist hinkfrei möglich, störend wirkt sich die Arthrodese beim Laufen aus.

- Langfristig Gefahr der Überlastung und Abnutzung benachbarter Gelenke.

- Dystrophien mit schmerzhaften Bewegungseinschränkungen in Fuß- und Zehengelenken.

- Schuhe mit hohem Absatz können nicht mehr getragen werden.

\section{Operationsvorbereitungen}

- Anfertigen von aktuellen Röntgenbildern des oberen Sprunggelenks in zwei Ebenen unter Belastung. Aufgrund der Röntgenaufnahme kann entschieden werden, ob eine „In-situ-Arthrodese“ oder eine korrigierende plane Resektion, evtl. gar mit Knochenaufbau, in Frage kommt.

- Bestimmung der Außenrotation des Fußes auf der gesunden Seite.

- Desinfizierendes Bad oder desinfizierende Dusche (Betadine ${ }^{\circledR}$ Seifenlösung, Mundipharma Medical Company, Hamilton, Bermudainseln) am Vorabend der Operation.

\section{Instrumentarium und Implantate}

- Kleine und mittlere Langenbeck-Haken (lang, schmal).

- Kleine stumpfe Hohmann-Hebel („Fibula-Hohmann").

- Gerade und gebogene Knochenmeißel (5 und 10 mm Klingenbreite).

- Arthrodesenspreizzange (schmal und breit).

- Oszillierende Säge.

- Bohrmaschine.

- 2,0 mm dicke Kirschner-Drähte.

- 4,5 oder 6,5 mm dicke Schrauben mit kurzem Gewinde, evtl. 6,5-mm-Hohlschrauben mit entsprechendem Instrumentarium.

- 3,5 mm dicke Kortikalisschrauben.

- Gewebeschutzhülse.

- Bildverstärker.
- Screws giving rise to symptoms can be removed after consolidation of arthrodesis.

- Normal gait without limp is possible. However, the arthrodesis limits the ability to run.

- Over time the added stress may lead to wear of neighboring joints.

- Risk of reflex sympathetic dystrophy with painful limitation of foot and toe movements.

- Shoes with high heels cannot be worn anymore.

\section{Preoperative Work Up}

- Radiographs of the ankle in two planes allowing a decision whether a simple arthrodesis can be done or whether a corrective resection or bone intercalation is necessary.

- Determination of the degree of external rotation of the opposite ankle.

- Disinfecting bath or shower (Betadine ${ }^{\circledR}$ solution, Mundipharma Medical Company, Hamilton, Bermuda) the night before surgery.

\section{Surgical Instruments and Implants}

- Small and mid-sized Langenbeck retractors (long, narrow).

- Small blunt Hohmann retractors ("fibula-Hohmann").

- Straight and curved chisels (5 and $10 \mathrm{~mm}$ wide).

- Arthrodesis spreader (narrow and large).

- Oscillating saw.

- Drill.

- 2.0-mm Kirschner wires.

- 4.5- or 6.5-mm lag screws, possibly $6.5-\mathrm{mm}$ cannulated screws with corresponding instruments.

- 3.5-mm cortical screws.

- Drill sleeve.

- Image intensifier. 


\section{Anästhesie und Lagerung}

- Intubationsnarkose, Spinal- oder Periduralanästhesie.

- Halbseitenlage auf einer Gelmatte; Seite der betroffenen Gliedmaße angehoben. Dazu werden Thorax und Becken mit Keilkissen in $45^{\circ}$ Schräglage gebracht. Zu beiden Seiten werden Stützen montiert, um ein gefahrloses Kippen des Operationstischs zu ermöglichen. Das Bein wird auf einem „Tunnelkissen" gelagert. Der unten liegende Arm kommt in $70^{\circ}$ Abduktion und leicht erhöht auf dem Armbänkchen zu liegen und wird fixiert. Der oben liegende Arm ruht auf dem flexiblen Armbänkchen, wobei der Oberarm $90^{\circ}$ flektiert wird (Abbildung 1).

- Eine pneumatische Blutsperre wird am Oberschenkel angelegt. Das Bein wird bis zur Blutsperremanschette desinfiziert und beweglich, d.h. bis oberhalb des Knies, steril abgedeckt. Nach Hochhalten des Beins für $30 \mathrm{~s}$ wird die Blutsperremanschette aufgeblasen.

\section{Anesthesia and Positioning}

- Endotracheal, spinal, or epidural anesthesia.

- Semilateral positioning on a gel mattress; wedged cushion under chest and pelvis. Stable fixation of the patient with kidney rests on both sides to allow a risk-free tilting of the operating table. The affected limb is elevated on a cushion with a "tunnel". The arm in contact with the table is positioned in $70^{\circ}$ of abduction on a slightly elevated arm support and stabilized. The other arm rests on an adjustable arm support with the upper arm in $90^{\circ}$ of flexion (Figure 1).

- Tourniquet at thigh; disinfection of the lower limb up to the tourniquet. Free draping of lower limb including the knee. Elevation of limb for $30 \mathrm{~s}$ and inflation of tourniquet.

\section{Abbildung 1 \\ Lagerung des Patienten. \\ Figure 1 \\ Positioning of the patient.}

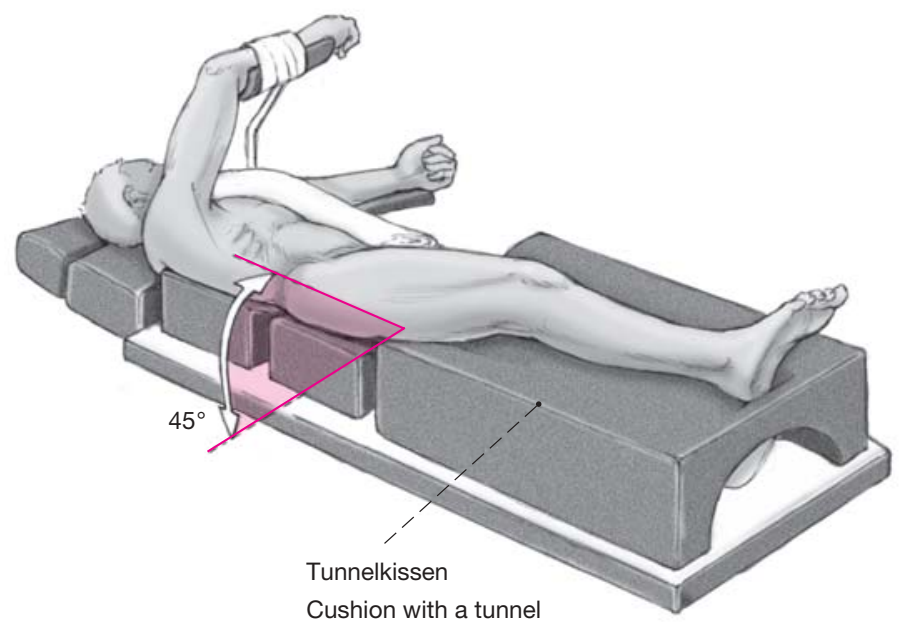

Cushion with a tunnel 


\section{Operationstechnik}

\author{
Abbildungen 2 bis 10
}

\begin{abstract}
Abbildung 2
Die Hautinzision beginnt $10 \mathrm{~cm}$ proximal der Fibulaspitze und wird an der Hinterkante der Fibula gegen distal geführt. Ab Fibulaspitze zieht die Inzision in Richtung der Metatarsale-IV-Basis bis auf Höhe des Kuboids. Der Zugang verläuft zwischen dem Nervus suralis und dem Nervus peroneus superficialis.
\end{abstract}

\section{Figure 2}

Skin incision starting $10 \mathrm{~cm}$ proximal to the tip of the lateral malleolus, continuing along the posterior border of the fibula in a distal direction, then at the level of the tip of the lateral malleolus curving in an anterior direction toward the base of the fourth metatarsus and ending at the level of the cuboid. The approach lies between the areas supplied by the sural nerve and the superficial peroneal nerve.

\section{Abbildung 3}

Sorgfältiges, strikt epiperiostales Darstellen der distalen Fibula, der vorderen Syndesmose und der gesamten ventralen Tibia bis zum Innenknöchel unter weitestmöglicher Schonung der periostalen Blutgefäße. Anheben der Weichteile über der ventralen Kapsel des oberen Sprunggelenks. Darstellen der distalen Kapselinsertion auf dem Talushals. Resektion der ventralen Kapsel. Entfernen der Osteophyten am Talushals und an der ventralen Tibialippe. Durchtrennen der Ligamenta fibulotibiale anterius und fibulocalcaneare sowie des vorderen Syndesmosenbandes.

\section{Figure 3}

Meticulous, strictly epiperiosteal exposure of the distal fibula, the anterior syndesmosis, and the entire anterior surface of the tibia up to the medial malleolus. The preservation of periosteal blood vessels is of utmost importance. Retraction of soft tissues overlying the anterior capsule of the ankle. Visualization of the distal capsular insertion into the talar neck. Resection of the anterior capsule. Removal of osteophytes from talar neck and anterior tibial rim. Division of the anterior fibulotibial, fibulocalcaneal and anterior tibiofibular ligaments.

\section{Surgical Technique}

\author{
Figures 2 to 10
}
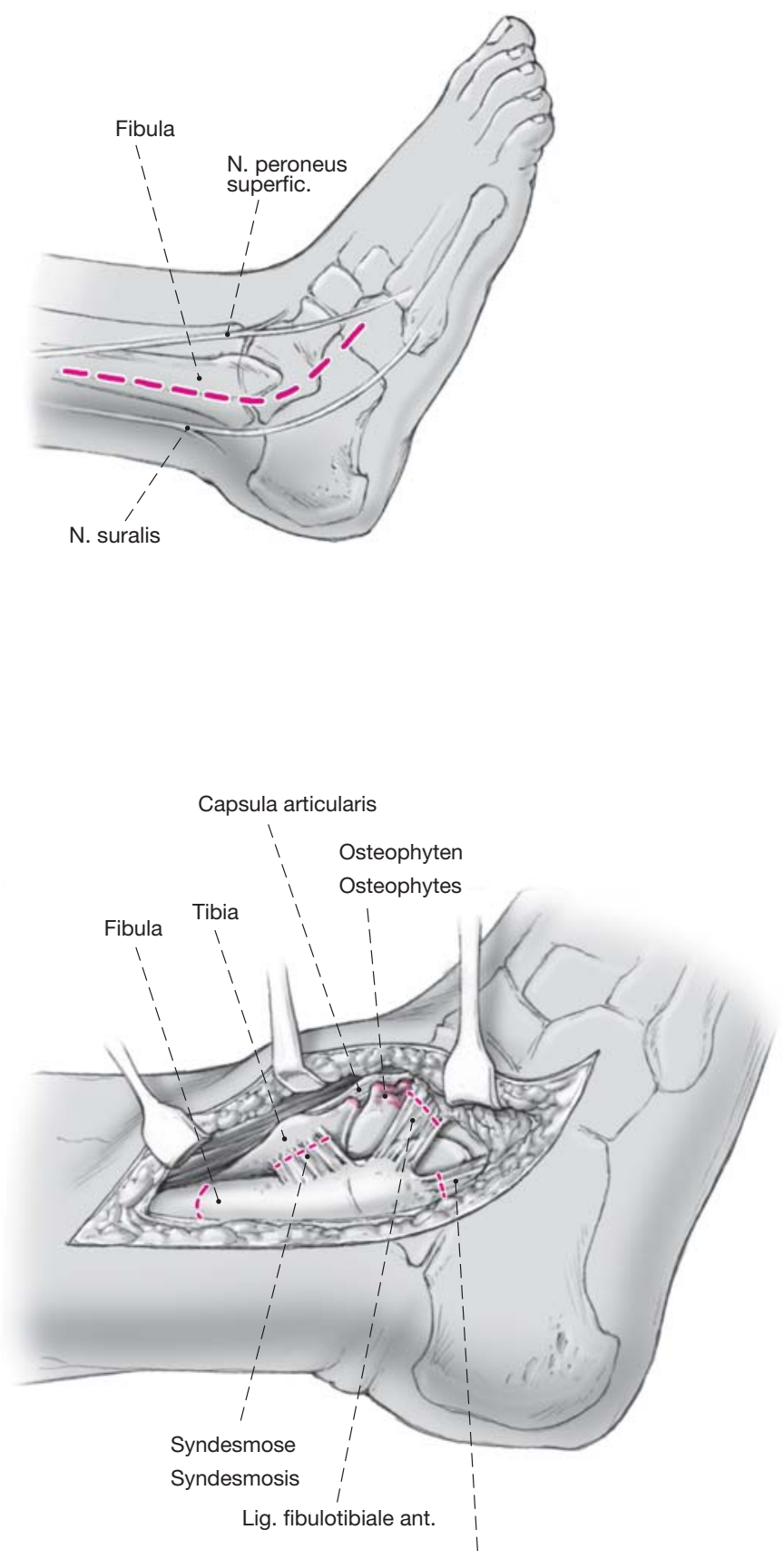

Lig. fibulocalcaneare 


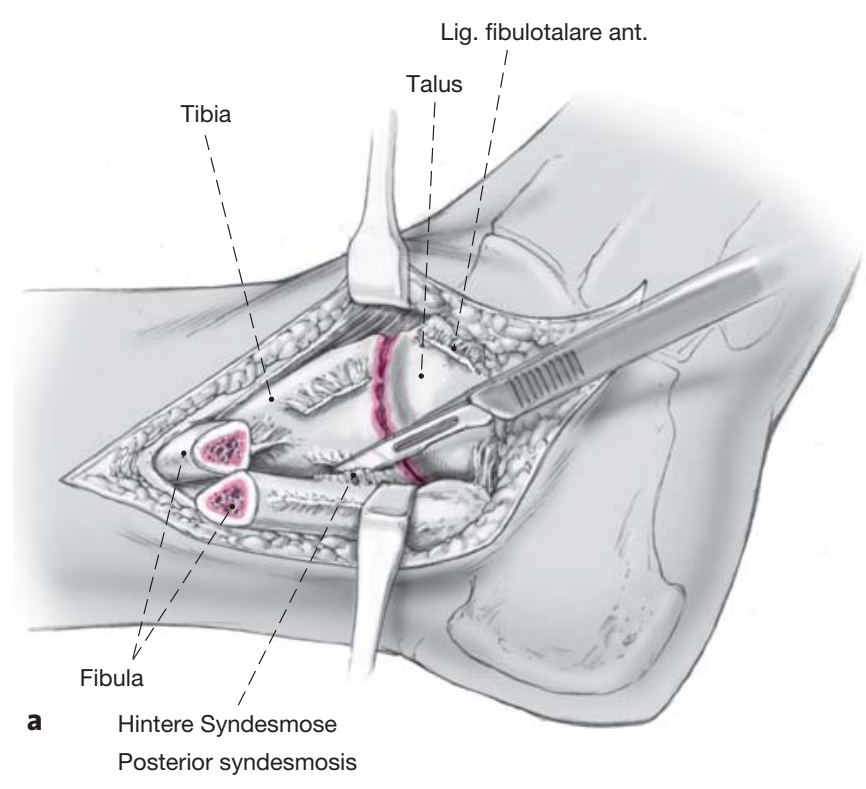

\section{Abbildungen $4 a$ und $4 \mathbf{b}$}

a) Das Periost der Fibula wird $3 \mathrm{~cm}$ oberhalb des Gelenkspalts schräg inzidiert. Die Fibula wird mit zwei stumpfen Hohmann-Hebeln umfahren, um die Weichteile zu schützen. Nun wird die Fibula mit der oszillierenden Säge von proximal-lateral nach distal-medial schräg osteotomiert und mit einem Langenbeck-Haken nach dorsal weggeklappt; das hintere Syndesmosenband wird dicht an der Tibia abgeschält. Es besteht nun eine gute Übersicht auf das gesamte obere Sprunggelenk, von ventral bis dorsal.

b) Außer bei einer „In-situ-Arthrodese“ ist es regelmäßig notwendig, die Spitze des Innenknöchels zu resezieren, da er sonst sperrt und es nicht möglich ist, die Knochenflächen medial aufeinander zu stellen; außerdem wäre die Reposition der häufigen ventralen Subluxation nicht möglich.

Arthrodese bei ausgesprochenen Fehlstellungen im oberen Sprunggelenk: Eine dorsomediale Längsinzision (entlang der Sehne des Musculus tibialis posterior) von $6 \mathrm{~cm}$ wird auf den Innenknöchel zentriert. Der Malleolus medialis wird subperiostal dargestellt, seine Spitze $(5-8 \mathrm{~mm})$ wird reseziert. Anschließend können der mediale Talus und die Lateralfläche des Innenknöchels angefrischt werden.

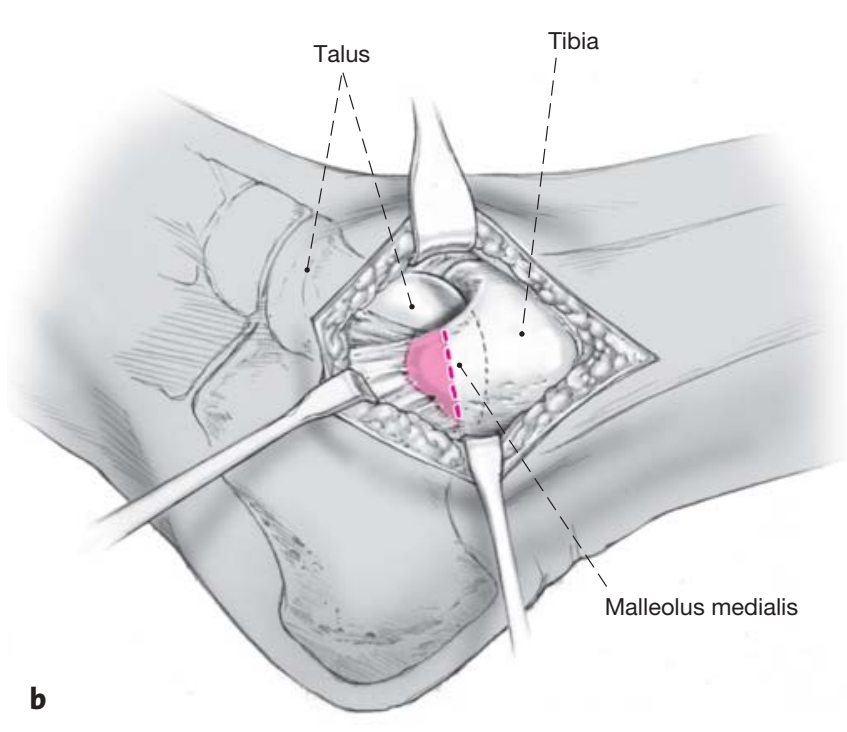

\section{Figures $4 a$ and $4 b$}

a) Oblique incision of the fibular periosteum $3 \mathrm{~cm}$ proximal to the joint space. Two blunt Hohmann retractors are inserted around the fibula for soft-tissue protection. Oblique fibular osteotomy with an oscillating saw from proximal lateral to distal medial. The fibula is now turned posteriorly with a Langenbeck retractor. The posterior tibiofibular ligament is detached from the tibia. Visualization of the entire ankle joint from anterior to posterior is now possible.

b) Resection of the tip of the medial malleolus is always necessary except in instances of a simple arthrodesis, because the tip will keep the bony surfaces apart and thus does not allow a bony contact on the medial side. Besides, without this resection a reduction of the frequently present anterior talar subluxation would not be possible.

Arthrodesis in instances of correction of malalignment: posteromedial incision, $6 \mathrm{~cm}$ long, along the tibialis posterior tendon centered on the medial malleolus. Subperiosteal dissection of the medial malleolus and resection of its tip $(5-8 \mathrm{~mm})$. Freshening of the medial gutter. 


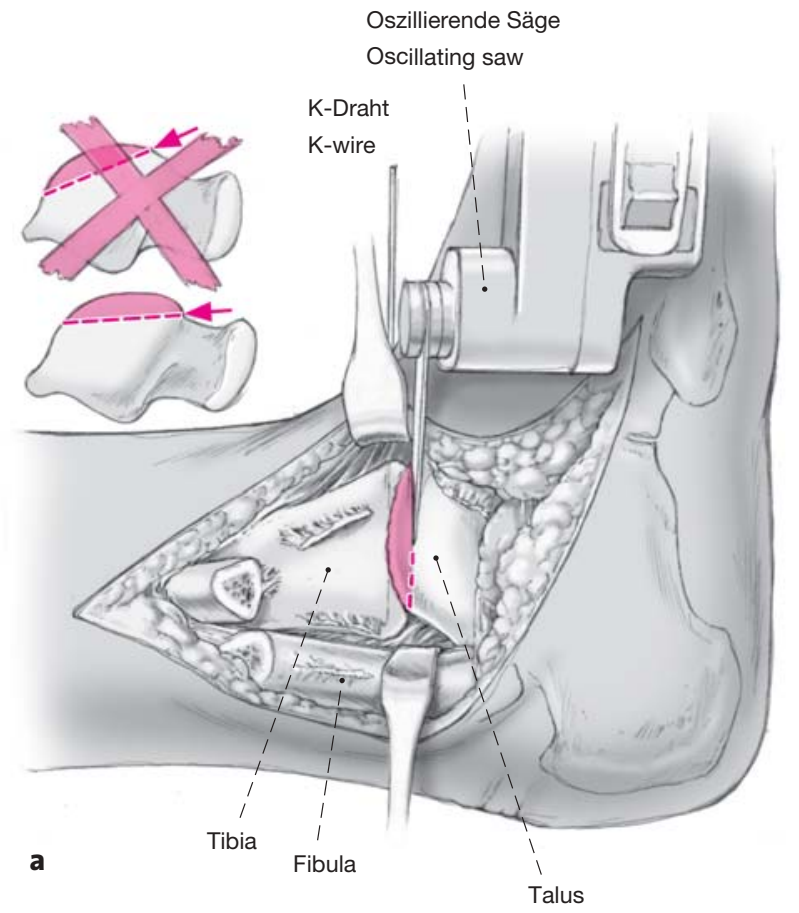

\section{Abbildungen 5 a und $\mathbf{5 b}$}

Von lateral wird mit der oszillierenden Säge zuerst der sog. Talusdom (tibiale Gelenkfläche) reseziert. Es ist darauf zu achten, dass das Sägeblatt parallel zur Fußsohle ausgerichtet ist und der Sägeschnitt am ventralen Ende des „Doms“ (Übergang zum Talushals) beginnt. Diese Gegend muss gut sichtbar sein, um zu verhindern, dass nur der hintere Anteil des Talusdoms reseziert wird. Es wird eine Scheibe von maximal $5 \mathrm{~mm}$ Dicke entfernt (a). Der Fuß wird nun in die gewünschte Position gebracht und vom Assistenten in dieser Stellung gehalten. Richtunggebende Kirschner-Drähte können auf die Resektionsfläche des Talus oder parallel dazu in die Tibia platziert werden; der Operateur kann auch den Sägeschnitt direkt an der Tibia ausführen, parallel zur Resektionsfläche des Talus (b). Die resezierte Scheibe soll so dünn wie möglich sein (knapp subchondral an der dünnsten Stelle). Der Sägeschnitt muss etwa $10 \mathrm{~mm}$ vor der medialen Tibiakortikalis enden, damit nicht der Innenknöchel mit entfernt wird. Als „Stopper“ kann ein Kirschner-Draht dienen, der von ventral in die gewünschte Position eingebracht wird.

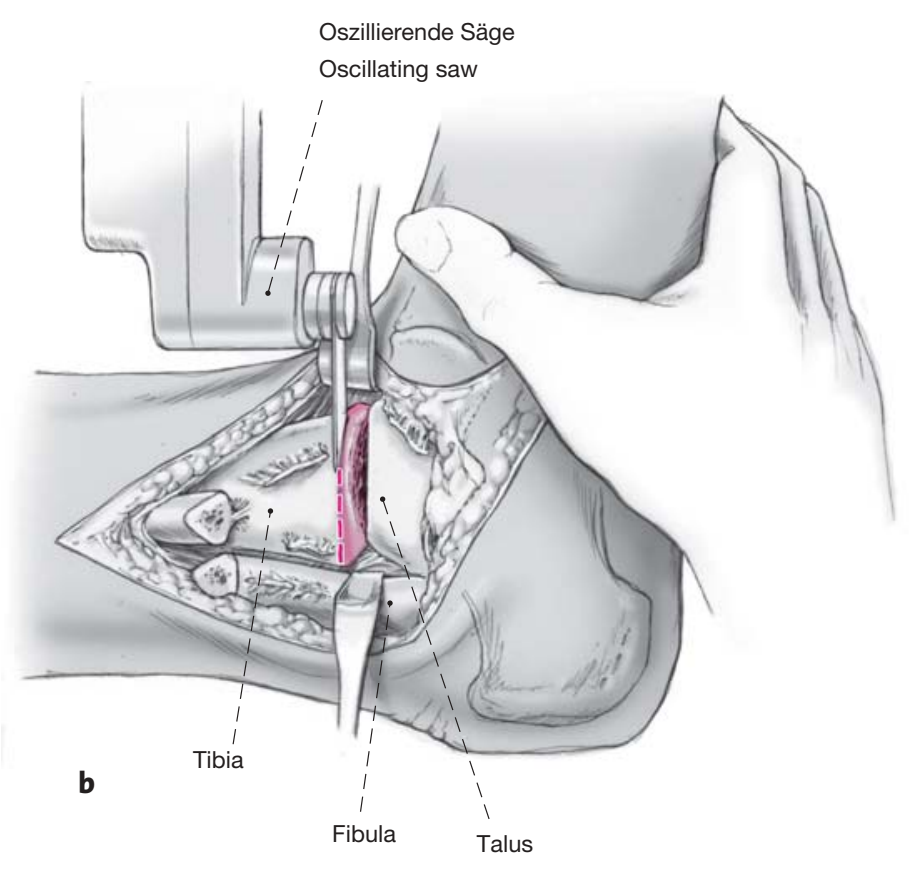

Figures $\mathbf{5} \mathbf{a}$ and $\mathbf{5 b}$

Resection of the articular surface of the talar dome from lateral with an oscillating saw. It is of importance that the saw blade is held parallel to the sole of the foot and that the cut starts at the anterior border of the talar dome. This area must be well visualized to prevent a resection of only the posterior part of the talar dome. A bony slice of maximally $5 \mathrm{~mm}$ thickness is removed (a). The foot is now brought into the desired position and kept there by the assistant. Guide wires may be placed on the surface of the talar resection or parallel to it into the tibia. Removal of the tibial articular surface parallel to the plane of the talar resection (b). The resected disk should be as thin as possible (barely subchondral at its thinnest place). The resection must stop $10 \mathrm{~mm}$ short of the medial tibial cortex to prevent an accidental osteotomy of the medial malleolus. A Kirschner wire inserted into the tibia from anterior into the site may be helpful to indicate where the resection must end. 


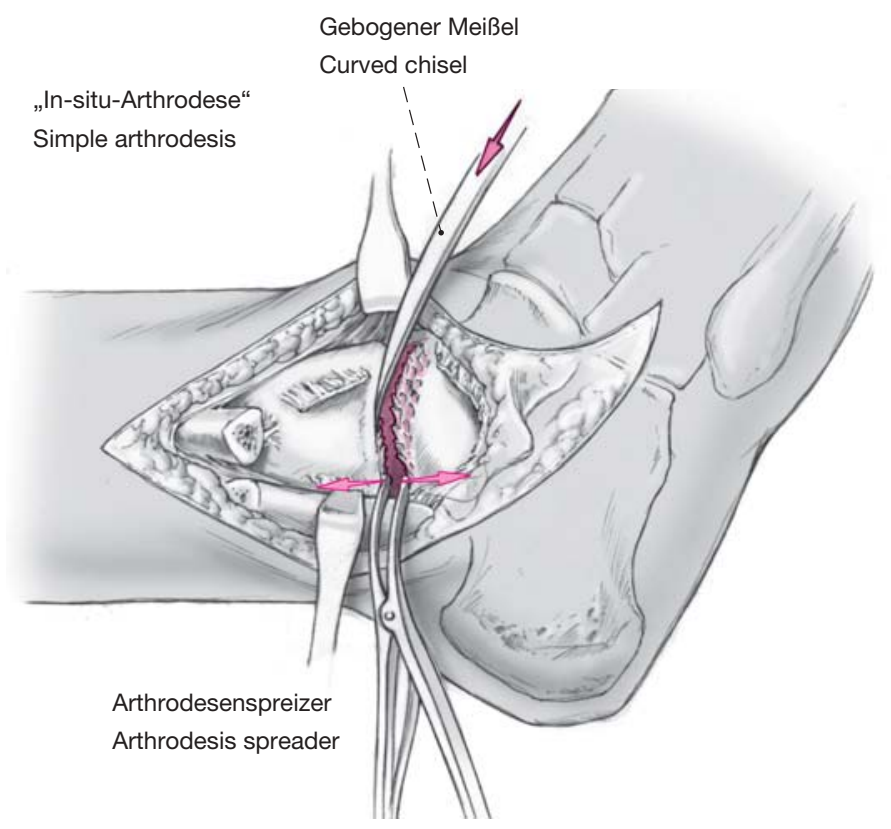

\section{Abbildung 6}

Sogenannte In-situ-Arthrodese: Falls keine Stellungskorrektur notwendig ist, können die Gelenkkonturen erhalten und die Flächen direkt mit dem gebogenen Meißel angefrischt werden. Es resultiert dann keine Verkürzung; die Anfrischung des Innenknöchels kann unterbleiben, wenn sich die Flächen auch medial gut adaptieren lassen. Zur guten Einsicht auf die Gelenkflächen wird das Sprunggelenk mit Arthrodesenspreizzangen distrahiert; die Zangen werden wechselweise ventral und dorsal angelegt. Schließlich wird die gesamte Arthrodesenfläche „dachziegelartig“ mit dem Meißel zur Vergrößerung der Knochenoberfläche und zur Reduktion der Oberflächenhärte präpariert. Dadurch werden der Knochenkontakt verbessert, die Stabilität erhöht und eine rasche Konsolidierung begünstigt.

\section{Figure 6}

Simple arthrodesis: if no correction of malalignment is necessary, the joint contours may be preserved and the surfaces freshened with a curved chisel. Such a procedure does not result in shortening of the limb. There is no need to freshen the medial gutter, if the surfaces can also medially be well adapted. The use of an arthrodesis spreader allows visualizing the articular surfaces. The tongues of the spreader can be alternately inserted into the anterior and posterior part of the ankle. To increase the contact surface, petals are created with the chisel reducing at the same time the hardness of the surface while increasing the stability. A faster consolidation will ensue. 


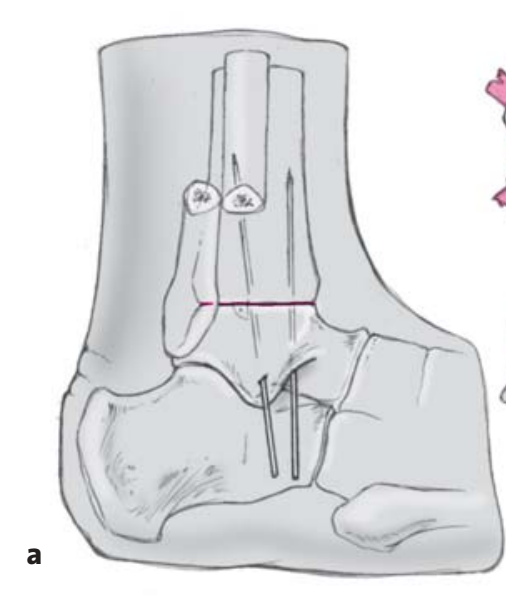

\section{Abbildungen $\mathbf{7 a}$ und $\mathbf{7 b}$}

Der Talus wird senkrecht unter die Tibia reponiert und in gewünschter Außenrotation mit zwei oder drei 2,0 mm dicken Kirschner-Drähten provisorisch fixiert (a). Bei der Reposition ist darauf zu achten, dass der Talus weit genug nach dorsal verschoben wird und nicht in ventraler Subluxation verbleibt. Dazu müssen die Osteophyten am Talushals bis ganz nach medial abgetragen worden sein. Die dorsale Begrenzung des Talus soll bündig mit der dorsalen Tibiakante stehen. Eine Versetzung des Taluszentrums weiter nach dorsal als der normalen Anatomie entsprechend ist gangphysiologisch ungünstig (eigene, nicht publizierte Untersuchungen). Die Fußsohle sollte nun in einer simuliert belasteten Prüfung (sterile Plexiglasplatte, die an die Sohle gedrückt wird) sowohl in der Sagittal- als auch in der Transversalebene rechtwinklig zum Unterschenkel (Referenzachse: Fibulaschaft; von der Osteotomie bis zum Fibulaköpfchen) stehen (b). Die Ferse darf eine geringe Valgität aufweisen; die Außenrotation sollte $15-20^{\circ}$ betragen (präoperativ auf der gesunden Gegenseite messen). Die Stellung der Arthrodese wird radiologisch mit dem Bildwandler in zwei Ebenen kontrolliert. Die korrekte Ausrichtung und die vollständige Adaptation der Knochenflächen werden dabei verifiziert.

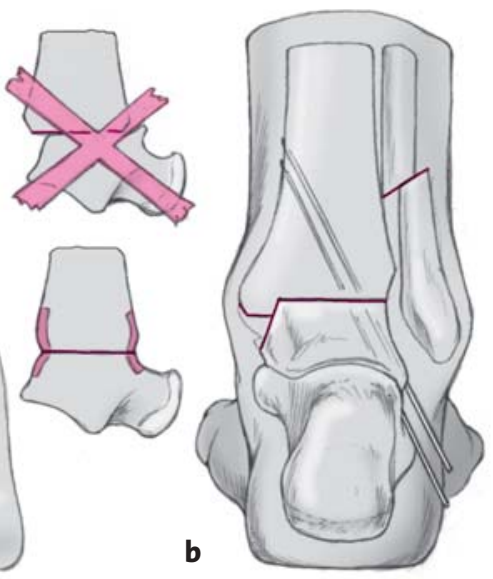

Figures $\mathbf{7 a}$ and $\mathbf{7 b}$

The talus is placed perpendicular to the tibia in the desired external rotation and provisionally held with two or three 2.0-mm Kirschner wires (a). Care has to be taken during the positioning that the talus is sufficiently pushed posteriorly and that no anterior subluxation remains. Osteophytes at the talar neck up to the medial side blocking the posterior displacement must be resected. The posterior border of the talus must be in line with the posterior tibial border. A further posterior displacement of the talar center, beyond its anatomic position, will have an unfavorable influence on the gait (personal, unpublished studies). To test the proper position of the arthrodesis, a flat plate (sterile acrylic glass plate) should be pressed against the sole of the foot. The foot should now be perpendicular to the lower leg in the sagittal and transverse plane (reference axis: fibular shaft from site of osteotomy to fibular head; $b$ ) The heel may be in slight valgus and the external rotation between $15^{\circ}$ and $20^{\circ}$ (as determined preoperatively on the opposite side).

The position of the arthrodesis is checked in two planes with the image intensifier. The correct position as well as the perfect adaptation of the bony surfaces must be verified. 

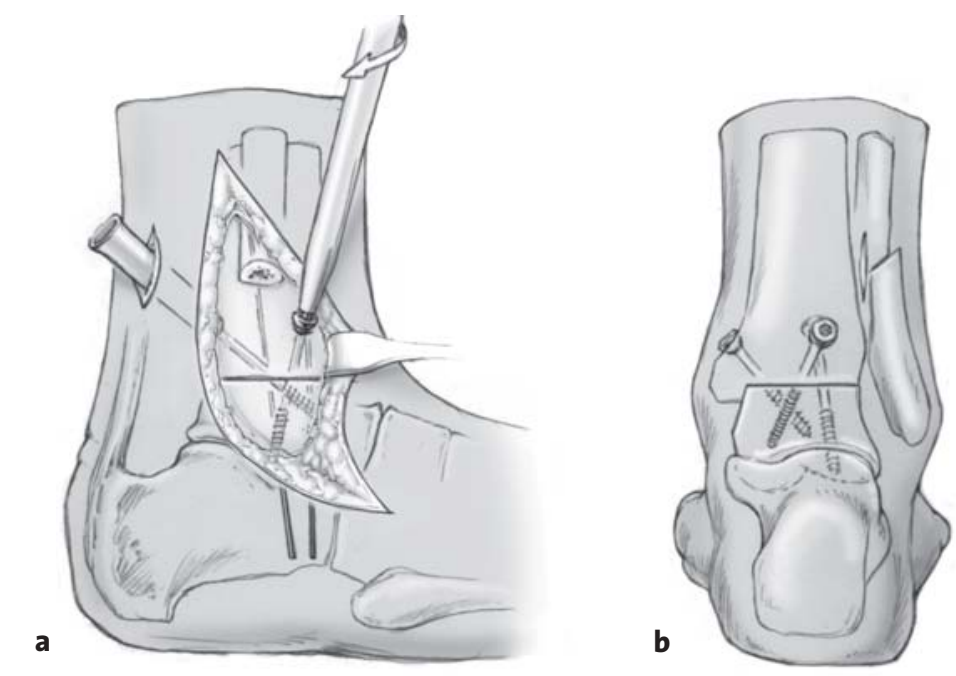

\section{Abbildungen $8 a$ und $8 b$}

a) Die Fixation beginnt mit einer Zugschraube von der dorsolateralen Tibia nach ventromedial in den Talushals/-kopf. Diese Schraube verhindert, dass der Talus wieder nach ventral rutscht; sie komprimiert die Resektionsflächen. Das Einbringen der Schraube ist über den bestehenden Zugang häufig nicht möglich. Eine zusätzliche Inzision von $3 \mathrm{~cm}$ Länge lateral und proximal der Achillessehne (cave: Nervus suralis) wird dazu benötigt. Zwischen Peronealmuskulatur und Musculus flexor hallucis longus wird stumpf bis auf die Tibiahinterfläche präpariert und eine große Schutzhülse (Innendurchmesser $9 \mathrm{~mm}$ ) eingeführt; durch sie kann nun ein Kirschner-Führungsdraht für eine Hohlschraube oder der Bohrer für eine konventionelle Zugschraube direkt eingebracht werden. Die Lage wird im Bildwandler kontrolliert. Danach wird die zweite Zugschraube von der ventrolateralen Tibia möglichst senkrecht in den zentralen, lateralen Taluskörper platziert. Je nach Elastizität der Weichteile sind auch hier - zur Schonung des ventralen Gefäß-Nerven-Bündels - eine zusätzliche kleine ventrale Inzision und die Verwendung der Schutzhülse notwendig. Die Schrauben werden nun wechselweise festgedreht, und die Stellung des Fußes wird im Bildwandler kontrolliert.

b) Wenn bei der manuellen Stabilitätsprüfung noch Wackelbewegungen möglich sind oder wenn im Röntgenbild medial noch ein Spalt verbleibt, kann proximal des Innenknöchels eine dritte Zugschraube in Richtung des Zentrums des Taluskörpers gesetzt werden. Nach unserer Erfahrung war dies selten notwendig. Im Übrigen ist es nicht erforderlich, diese Schraube weit dorsal-medial zu setzen, da dort die Weichteilspannung (Achillessehne) einen Zuggurtungseffekt ausübt und somit stabilisieren hilft.

\section{Figures $8 a$ and $\mathbf{8 b}$}

a) The internal fixation starts with a lag screw introduced into the tibia posterolaterally and directed anteromedially into the talar neck and head. This screw prevents an anterior redisplacement of the talus and compresses the resection surfaces. It is often impossible to insert the screw through the existing approach necessitating an additional $3 \mathrm{~cm}$ long incision lateral and proximal to the Achilles tendon (attention: sural nerve). Blunt preparation between peroneal muscles and flexor hallucis longus up to the posterior tibial surface and insertion of a big drill guide (inner diameter $9 \mathrm{~mm}$ ). A guide wire for a cannulated screw or a drill bit for a normal lag screw can now be introduced through the sleeve. The position is checked with the image intensifier. A second lag screw is then introduced into the anterolateral surface of the tibia as vertical as possible and advanced in the center of the lateral portion of the talar body. Depending on the elasticity of the soft tissues and to avoid stretching of the anterior neurovascular bundle, an additional small anterior incision and the use of a drill sleeve may become necessary. The screws are alternately tightened while checking the position of the foot with the image intensifier.

b) If the manual testing for stability reveals movements or if a medial gap remains as seen on the radiograph, a third lag screw can be inserted proximal to the medial malleolus in direction of the mid part of the talar body. In our experience this was only rarely necessary. Besides, it is not necessary to place this screw too far posterior and medial, since the soft-tissue tension (Achilles tendon) exerts a tension band effect thus increasing the stability. 


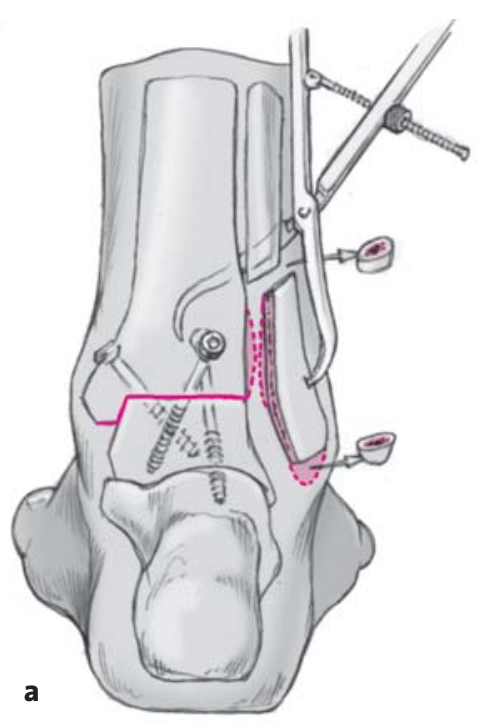

\section{Abbildungen 9a und $9 b$}

Nach tibiotalarer Fixation wird die mediale Kortikalis des Außenknöchels mit der oszillierenden Säge entfernt. Der Außenknöchel wird so zugerichtet, dass er ohne Lücken an die laterale tibiotalare Kontur passt. Wegen resektionsbedingter tibiotalarer Verkürzung müssen 5-10 mm Fibula reseziert werden. Dieses Fibulasegment, die evtl. störende Fibulaspitze und der vorher resezierte Knochen können als Spongiosabröckchen um das Resektionsgebiet angelagert werden. Die Incisura fibulae (Syndesmosenraum) an der Tibia wird angefrischt. Mit einer spitzen Repositionszange wird der dorsal weichteilgestielte Außenknöchel nach ventral gezogen, an die Tibia und die laterale Taluswange gelagert (a) und mit zwei 3,5-mm-Kortikalisschrauben als Zugschrauben fixiert (uni- oder bikortikal, je nach Knochenqualität; b).

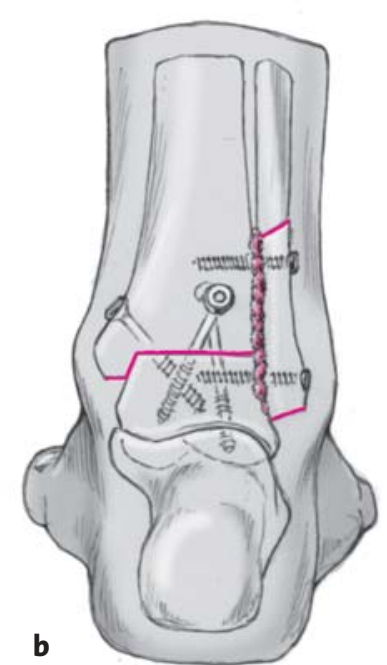

\section{Figures $9 a$ and $\mathbf{9 b}$}

Once the tibiotalar fixation is completed, the medial cortex of the lateral malleolus is removed with an oscillating saw. The lateral malleolus is fashioned in a way to permit an intimate contact with tibia and talus. Given the shortening due to the tibiotalar arthrodesis, the fibula has to be shortened by 5-10 $\mathrm{mm}$. The removed segment, the resected tip of the lateral malleolus, and the previously resected bones can be positioned as bone grafts around the area of arthrodesis. The lateral surfaces of tibia and talus will be freshened. Using a sharp reduction forceps the posteriorly pedicled lateral malleolus is pulled anteriorly, apposed to tibia and lateral surface of talus (a) and fixed with two 3.5-mm cortical screws using the lag screw principle (uni- or bicortical fixation depending on the quality of bone; $b$ ). 


\begin{abstract}
Abbildung 10
Die Periostlefzen an der Tibia und am Außenknöchel sowie die Bandstümpfe können mit einer fortlaufenden Naht adaptiert werden. Dies dient vor allem zur Verkleinerung des Hohlraums und damit zur Hämatomprophylaxe. Eine Saugdrainage wird eingelegt; die Faszie und Subkutis werden mit resorbierbarem Faden der Stärke 2-o oder 3-o verschlossen.

Hautnaht mit nicht resorbierbarem Faden der Stärke 3-o oder 4-o in Donati-Technik. Medial werden Periost und Stumpf des Ligamentum deltoideum vernäht; dann werden Subkutis und Haut in gleicher Technik wie lateral verschlossen. Eine Saugdrainage medial ist nicht notwendig, da der Raum mit dem lateralen Zugang kommuniziert.

Röntgenaufnahmen des oberen Sprunggelenks in zwei Ebenen.

\section{Figure 10}

The periosteal flaps of tibia and lateral malleolus as well as the ligament stumps are adapted with running sutures. This will avoid the formation of a dead space and therefore serves as prevention of blood accumulation. Suction drain, closure of fascia and subcutaneous tissue with 2-o or 3-o resorbable sutures. Skin closure with nonresorbable 3-o or 4-o sutures using the Donati technique. Medially, the stump of the deltoid ligament is sutured to the periosteum followed by sutures of subcutaneous tissue and skin in the same way as done laterally. A suction drain is not necessary, as the cavity communicates with the lateral approach.

Radiographs of the ankle in two planes.
\end{abstract}

\section{Postoperative Behandlung}

- Ein gut gepolsterter Unterschenkelliegegipsverband wird unmittelbar postoperativ angelegt. Am 2. postoperativen Tag erster Verbandswechsel. Die Saugdrainage wird entfernt, und ein einfacher Wundverband wird angelegt. Bei „trockenen“ Wunden und nach ausreichender Abschwellung - meist am 3.-4. postoperativen Tag - wird ein leichter Kunststoffliegegipsverband (Soft-Scotchcast ${ }^{\mathrm{TM}}$ ) angelegt. Damit kann der Patient aufstehen und mit vollständiger Stockentlastung gehen. 10-14 Tage postoperativ werden die Nähte entfernt, und ein neuer Kunststoffgipsverband wird angepasst, mit dem der Patient für die nächsten 4 Wochen mit 10-15 kg Belastung gehen darf. Eine Übungsbehandlung (Physiotherapie) ist nur bei gehunsicheren Patienten notwendig. 6 Wochen postoperativ wird der Gipsverband entfernt, und das obere Sprunggelenk wird in zwei Ebenen geröntgt. Bei ungestörter Heilung darf der Patient anschließend mit 25-30 kg Belastung gehen, geschützt im Kunststoffgehgipsverband (gehunsichere Patienten) oder mit einem sog. Stabilschuh. Ein Kompressi-

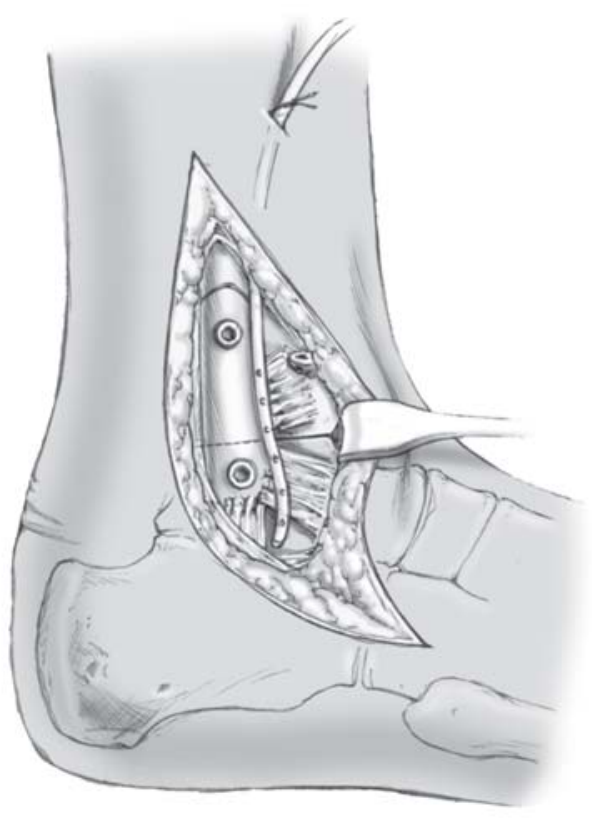

\section{Postoperative Management}

- A below-knee, well-padded nonwalking plaster cast is applied immediately after surgery. Dressing change on postoperative day 2. Removal of suction drain, simple dressing. Provided the wound is dry and there is little swelling, a light Soft-Scotchcast ${ }^{\mathrm{TM}}$ is applied. This allows the patient to leave the bed and ambulate with the support of a cane. 10-14 days after surgery the sutures are removed, and another Soft-Scotchcast ${ }^{\mathrm{TM}}$ is made; the patient is now allowed to weight-bear up to $10-15 \mathrm{~kg}$ for the next 4 weeks. Physiotherapy is only indicated, if the patient experiences difficulties walking with the cast. 6 weeks postoperatively the cast is removed and radiographs of the ankle are taken in two planes. In instances of good consolidation the patient may progress to partial $(25-30 \mathrm{~kg})$ weight bearing, protected by a walking cast (only for patients feeling unsure) or a support boot. Due to edema tendency compression stockings are recommended. Next radiographic control at 10 weeks. If consolidation progresses satisfactorily, weight bearing is in- 
onsstrumpf ist wegen der Schwellungstendenz ratsam. Nach 10 Wochen nächste Röntgenkontrolle. Bei guter Konsolidierung kann zunehmend bis vollständig belastet werden. 3 Monate postoperativ ist meist Gehen ohne Stützen möglich.

- Thrombose-/Embolieprophylaxe (niedermolekulares Heparin) bis zur gipsverbandfreien Vollbelastung. Störende Schrauben können nach Erreichen der Arthrodese jederzeit entfernt werden. AbschlieBende klinische und radiologische Kontrolle $1 \mathrm{Jahr}$ nach der Operation.

\section{Fehler, Gefahren, Komplikationen}

- Varus-, Valgus-, Flexions- oder Extensionsfehlstellung des Talus: Korrektur durch Nachresektion, nach Möglichkeit nur an der Tibia, da sonst die Schraubenverankerung im Talus gefährdet wird! Falls sehr viel Knochen reseziert werden muss, ist ein knöcherner Aufbau durch Interposition eines Spans (autogener Knochenspan aus dem Beckenkamm) zu erwägen.

- Eine zu weit ventrale Position des Talus: Entsteht, wenn die vorderen Talusosteophyten (vor allem medial), die Innenknöchelspitze oder die hintere Tibialippe nicht entfernt worden sind. Die entsprechende Nachresektion wird ein korrektes Platzieren des Talus erlauben. Ein Rückversetzen des Talus ist nur bei plan resezierten Flächen möglich.

- Statt der Spitzenregion wird der mediale Malleolus vollständig entfernt: Refixation mit zwei 3,5-mmKortikalisschrauben erforderlich.

- Verzögerte oder fehlende Heilung (Pseudarthrose): Revisionsoperation mit erneutem Anfrischen der Gelenkflächen, Beseitigen von Sklerosezonen, Einbringen von Spongiosa und komprimierende Fixation der Gelenkflächen.

- Verletzung des Nervus suralis oder des lateralen Asts des Nervus peroneus superficialis: Nervennaht mit Hilfe von Lupenbrille oder Mikroskop.

- Verletzung des Nervus tibialis: Revision des Nervs durch den dorsomedialen Zugang. Spalten des Retinaculum musculorum flexorum (Tarsaltunnelrelease). Nervennaht mit Hilfe des Operationsmikroskops.

- Verletzung der Arteria tibialis posterior: Revision der Arterie durch den dorsomedialen Zugang. Arteriennaht unter dem Operationsmikroskop.

- Störende Schraubenköpfe: Schrauben können entfernt werden, sobald die Arthrodese erreicht ist.

- Ausheilung in Spitzfußstellung: Absatzerhöhung. Falls die Fußstellung stark stört, Osteotomie und erneute Arthrodese. creased to full weight bearing. Usually, at 3 months postoperatively walking without any support is possible.

- Prevention of thrombophlebitis/embolism with low molecular heparin till full weight bearing without a cast. Symptomatic screws may be removed any time once the fusion is complete. Final clinical and radiographic control at 1 year postoperatively.

\section{Errors, Hazards, Complications}

- Talar malalignment in varus, valgus, flexion, or extension: correction done by a further resection, if ever possible, only at the tibia. Otherwise, the talar screw anchorage is endangered! In case of an extensive resection, interposition of a bone graft (autogenous bone graft harvested from the iliac crest) should be considered.

- Talus being too anteriorly positioned: often caused, if anterior talar osteophytes (especially on the medial side), the tip of the medial malleolus, or the posterior tibial rim have not been removed. The necessary reresection will permit a correct placement of the talus. A talar repositioning is only feasible, if the resected planes are flat.

- Complete resection of the medial malleolus instead of the tip only: refixation with two $3.5-\mathrm{mm}$ cortical screws.

- Delayed union or nonunion (pseudarthrosis): revision including freshening of the articular surfaces, debridement of sclerotic zones, application of corticocancellous bone, and fixation with compression screws.

- Injury to the sural nerve or the lateral branch of the superficial peroneal nerve: suture under magnifying glass or microscope.

- Injury to the tibial nerve: nerve exploration through a dorsomedial approach. Splitting of the flexors' retinaculum (tarsal tunnel release). Microscopic suture.

- Injury to the posterior tibial artery: exploration through a dorsomedial approach, microscopic vessel suture.

- Symptomatic screw heads: screws may be removed after complete consolidation of the arthrodesis.

- Pes equinus position after consolidation: lifting of heel. If very symptomatic, osteotomy and repeated arthrodesis. 


\section{Ergebnisse}

Von Januar 1997 bis Mai 2001 wurden bei 22 Patienten insgesamt 23 obere Sprunggelenke in der beschriebenen Technik operiert. 19 Patienten mit 20 Arthrodesen konnten klinisch und radiologisch $>1$ Jahr postoperativ nachkontrolliert werden. Ein Patient war nicht auffindbar; zwei Patienten litten unter schweren psychischen Erkrankungen und konnten nicht zur Nachuntersuchung erscheinen. Die mittlere Nachkontrollzeit betrug 39 Monate (12-69 Monate).

Das mittlere Alter der vier Frauen und 15 Männer lag zum Zeitpunkt der Operation bei 52 Jahren (27-75 Jahre). Die Operationsindikation war bei zehn Patienten eine posttraumatische Arthrose, bei vier ein zerstörtes Sprunggelenk bei Hohlfuß im Rahmen einer neurologischen Erkrankung, bei drei eine primäre Arthrose, bei zwei eine infektiöse Arthritis und bei einem Patienten eine Arthrose bei Hämochromatose. Bei einem Patienten wurden im Abstand von 13 Monaten das rechte und das linke obere Sprunggelenk versteift. Bei vier Patienten war eine kombinierte obere und untere Sprunggelenkarthrodese oder eine obere Sprunggelenkarthrodese bei bereits versteiftem unteren Sprunggelenk erforderlich.

Ausgeschlossen wurden Patienten mit Arthrodesen des Sprunggelenks nach anderer Technik, wie z.B. arthroskopische oder offene Entknorpelung und Benutzung eines Fixateur externe.

Radiologisch waren alle Arthrodesen des oberen Sprunggelenks nach 3 Monaten und zum Zeitpunkt der letzten Untersuchung stabil konsolidiert. In einem Fall lag anstelle der gewünschten orthograden Einstellung des Fußes eine Plantarflexionsstellung von $3^{\circ}$ vor. Bei einem Patienten kam es an der Fibula zu einer Pseudarthrose, die bei Beschwerdearmut keiner Therapie bedurfte (Abbildungen 11a bis 11d). Bei sieben Arthrodesen zeigten die benachbarten Gelenke (unteres Sprunggelenk, Chopart- und Lisfranc-Gelenk) noch keinerlei Anzeichen einer Degeneration; acht Patienten wiesen leichte degenerative Veränderungen talonavikular auf, sechs im unteren Sprunggelenk (Abbildungen 12a bis 12d) in Form leicht vermehrter subchondraler Sklerosen und minimaler Verschmälerung des Gelenkspalts. Je einmal traten degenerative Veränderungen im Kalkaneokuboidgelenk sowie im medialen navikulokuneiformen Gelenk auf.

Bei der klinischen Nachuntersuchung waren die Patienten mehrheitlich sehr zufrieden. Der Rückfußscore der AOFAS (American Orthopedic Foot and Ankle Society) [16] erlaubt maximal 86 Punkte, wenn Flexion/Extension (8 Punkte möglich) und Inversion/

\section{Results}

Between January 1997 and May 2001, the described technique has been employed in 22 patients (23 ankle joints). Clinical and radiologic follow-up after $>1$ year was done in 19 patients (20 ankle joints). One patient could not be localized, two suffered from severe psychiatric illnesses and were unable to present themselves for a follow-up. The average follow-up time was 39 months (12-69 months).

The average age of the four women and 15 men at the time of surgery was 52 years (27-75 years). The surgical indication was a posttraumatic arthritis in ten patients, a severely damaged ankle joint with pes cavus due to a neurologic disease in four, a primary osteoarthritis in three, an infectious arthritis in two, and an arthritis due to hemochromatosis in one. In one patient we performed a bilateral arthrodesis 13 months apart. In four patients it was necessary to do a combined arthrodesis of ankle and subtalar joints or to perform an ankle joint arthrodesis where a subtalar joint arthrodesis had already been done.

We did not include patients who underwent an ankle arthrodesis done by different methods, such as arthroscopy or cartilage resection and application of an external fixator.

On radiographs taken 3 months postoperatively and at the time of the last follow-up all arthrodeses were consolidated. In one patient we noted a foot in a plantar flexion position of $3^{\circ}$ instead of the desired orthograde position. In another patient the fibular osteotomy did not consolidate and ended in a pseudoarthrosis; as the patient did not complain, no treatment was instituted (Figures 11a to 11d). In seven patients we could not detect signs of degeneration in the neighboring joints (subtalar, Chopart and Lisfranc joints); however, eight patients showed slight degenerative changes in the talonavicular joint, in six patients we noted slightly increased sclerosis and minimal narrowing of the subtalar joint space (Figures 12a to $12 \mathrm{~d}$ ). We observed degenerative changes once in the calcaneocuboid joint and once in the medial naviculocuneiform joint.

At the time of follow-up most of the patients were very satisfied with the surgical result. The AOFAS (American Orthopedic Foot and Ankle Society) hindfoot score [16] gives a maximum of 86 points under condition that flexion/extension (maximum 8 points) and inversion/eversion (maximum 6 points) are excluded. Nine of our patients reached 86 points, eight between 70 and 84 points, and three between 40 and 58 points. The patient scoring 40 points suffered from a spinal muscle atrophy limiting her mobility. Muscle 

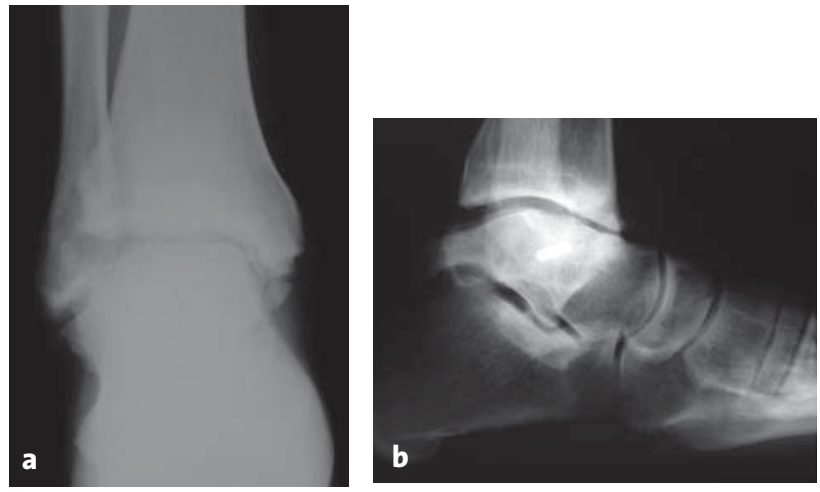

Abbildungen 11a und 11b

35-jähriger Patient mit schwerer posttraumatischer Sprunggelenkarthrose, 10 Jahre nach Talusfraktur.

\section{Figures 11a and 11b}

35-year-old patient with severe posttraumatic osteoarthritis of the ankle 10 years after talar fracture.
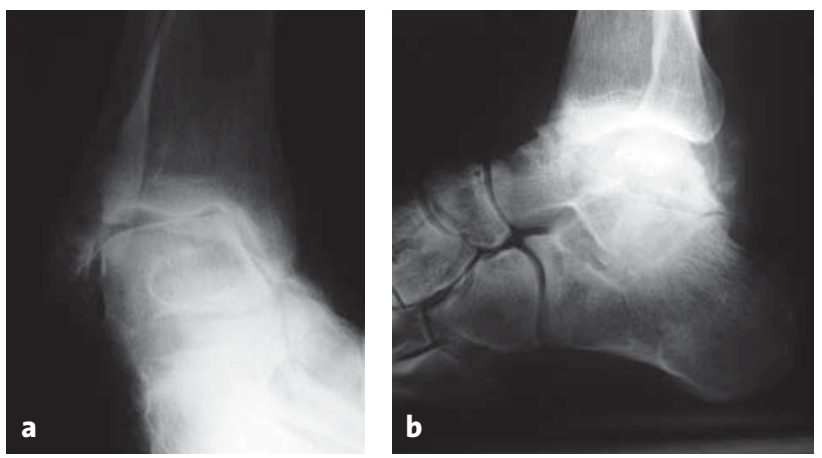

\section{Abbildungen 12a und 12b}

56-jähriger Patient mit Polyneuropathie unklarer Genese sowie seit Kindheit bestehender Varusinstabilität des Rückfußes mit Hohlfuß. Röntgenaufnahmen anteroposterior und seitlich.

\section{Figures $12 a$ and $12 b$}

56-year-old patient with polyneuropathy of unclear origin as well as a varus instability of the hindfoot with cavus foot present since childhood. Radiographs in anteroposterior and lateral projection.
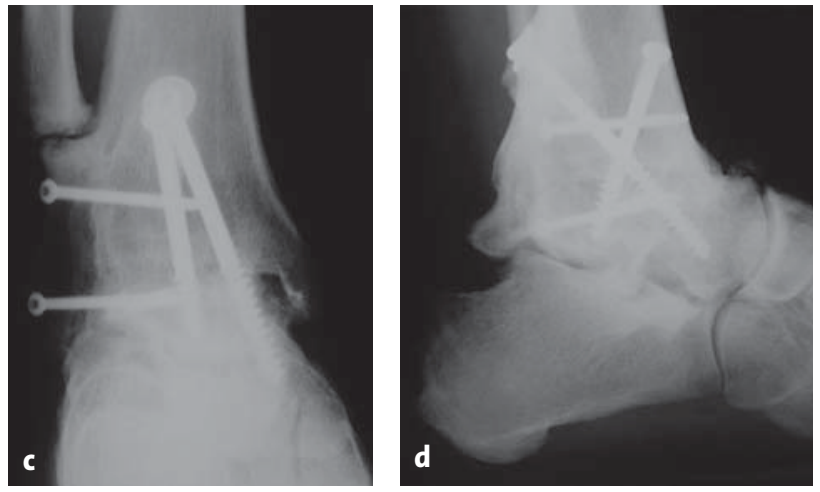

\section{Abbildungen 11c und 11d}

5 Jahre nach Sprunggelenkarthrodese über den transfibularen Zugang. Korrekte Stellung des Rückfußes; konsolidierte Arthrodese mit asymptomatischer Fibulapseudarthrose. Keine wesentlichen degenerativen Veränderungen im Bereich des Chopart-Gelenks.

\section{Figures 11c and 11d}

5 years after ankle arthrodesis through a transfibular approach. Correct position of the hindfoot, solidly fused arthrodesis with asymptomatic fibular nonunion.
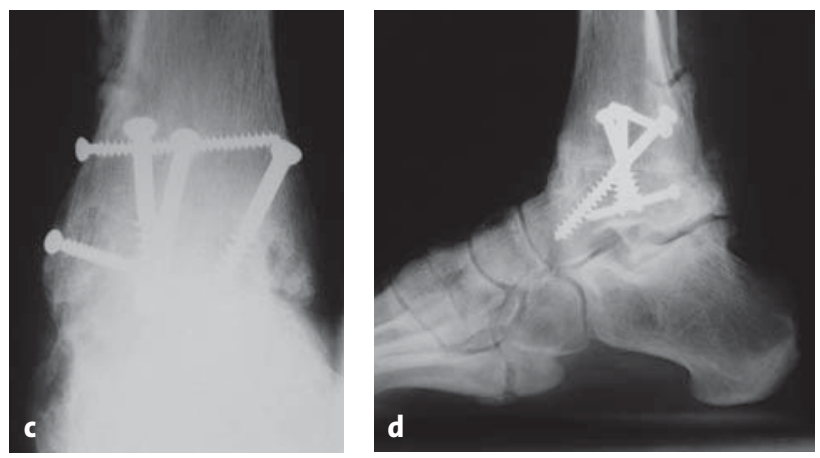

\section{Abbildungen 12c und 12d}

5 Jahre nach Arthrodese des oberen Sprunggelenks über den transfibularen Zugang. In diesem Beispiel wurde auch von medial operiert. Im Seitenbild zeigen sich diskrete degenerative Veränderungen am unteren Sprunggelenk, welche bisher asymptomatisch sind. Korrekte Stellung der Arthrodese.

\section{Figures $12 \mathrm{C}$ and 12d}

5 years after ankle arthrodesis through a transfibular approach. In this case a medial approach was also done. The lateral radiograph shows discrete, asymptomatic changes of the subtalar joint. Correct position of the consolidated arthrodesis. 
Eversion (6 Punkte möglich) ausgeklammert werden. Danach erreichten neun Patienten 86 Punkte. Bei acht Patienten wurde eine Punktzahl zwischen 70 und 84 und bei drei zwischen 40 und 58 erreicht. Die Patientin mit 40 Punkten litt unter einer spinalen Muskelatrophie und war wegen ihres Grundleidens nur eingeschränkt mobil. Morgendliche Muskelschmerzen sowie belastungsabhängige Schmerzen in beiden Füßen im Verlauf des Tages veranlassten sie zu regelmäßiger Schmerzmitteleinnahme. Sie empfand jedoch den aktuellen Zustand eindeutig besser als den früheren.

Der durchschnittliche AOFAS-Score betrug 78,5 Punkte (40-86 Punkte).

Insgesamt traten sieben Komplikationen auf: Bei einem Patienten trat nach der Arthrodese eine Verstärkung einer vorbestehenden Hypästhesie des Nervus tibialis und des Nervus peroneus superficialis auf, welche vom Unfall (Bergsturz mit Pilon-tibiale-Trümmerfraktur, Osteosynthese und sekundärer Fehlstellung) herrührte. Bei einem anderen Patienten war postoperativ eine Hypästhesie des gesamten Nervus tibialis bemerkt worden. Trotz sofortiger Dekompression (intraoperativ narbig eingebackener Nerv retromalleolär nach multiplen Distorsionen) verblieb schließlich eine Hypästhesie an der Großzehe. Wahrscheinlich hatte das intraoperative Distrahieren mit Spreizzangen zu einem Traktionsschaden des narbenfixierten Nervs geführt. Eine dritte Patientin beklagte postoperativ eine Hypästhesie der Großzehe; ein klarer Grund dafür konnte nicht gefunden werden. Die Gefühlsstörung war bei der letzten Kontrolle 13 Monate postoperativ weitgehend zurückgegangen.

Weitere Komplikationen umfassten ein postoperatives Hämatom, welches ausgeräumt wurde, eine spontan ausheilende, oberflächliche Wundrandnekrose lateral bei dem Patienten mit Hämochromatose, eine behandlungsbedürftige Algodystrophie und eine Fibulapseudarthrose, welche aufgrund der milden und nur intermittierend auftretenden Beschwerden bisher nicht behandelt werden musste. pain in the morning and activity-related pain of both feet during the day were severe enough to take analgesics regularly. She reported, however, that her condition had definitely improved.

The average AOFAS score amounted to 78.5 points (40-86 points).

We encountered seven complications: one patient was left with an increase of a preexisting hypoesthesia in the territories of the tibial and superficial peroneal nerves. This hypoesthesia had been caused by an accident (fall during mountain climbing, resulting in a comminutive pilon-tibial fracture, that was internally fixed and followed by a secondary malalignment). In another patient, a hypoesthesia of the entire territory of the tibial nerve was noted postoperatively. In spite of an immediate decompression (retromalleolar scar tissue enveloping the nerve secondary to multiple sprains), the hypoesthesia persisted at the level of the great toe. Most probably, the intraoperative distraction with the spreader had led to a traction damage to the nerve embedded in scar tissue. Postoperatively, a third patient complained of a hypoesthesia of the great toe; we were unable to determine the cause. The sensory disturbance had regressed considerably 13 months postoperatively.

Further complications included one postoperative hematoma that needed evacuation, one superficial necrosis of the wound edges in the hemochromatosis patient, that healed spontaneously, one reflex sympathetic dystrophy requiring treatment, and one pseudarthrosis of the fibula that needed no treatment as it caused only mild and intermittent symptoms. 


\section{Literatur - References}

1. Adams JC. Arthrodesis of the ankle joint. Experiences with the transfibular approach. J Bone Joint Surg Br 1948;30:506-11.

2. Allredge RH. Diastasis of the distal tibiofibular joint and associated lesions. JAMA 1940;115:2136-40.

3. Anderson T, et al. Uncemented STAR total ankle prostheses. Three to eight year follow-up of fifty-one consecutive ankles. J Bone Joint Surg Am 2003;85:1321-9.

4. Bauer G, Kinzl L. Arthrodesen des oberen Sprunggelenks. Orthopäde 1996;25:158-65.

5. Buchner M, Sabo D. Ankle fusion attributable to posttraumatic arthrosis: a long term follow up of 48 patients, Clin Orthop 2003;406: $155-64$.

6. Buechel FF, et al. Ten year evaluation of cementless Buechel-Pappas meniscal bearing total ankle replacement. Foot Ankle Int 2003; 24:462-72.

7. Charnley J. Compression arthrodesis of the ankle and shoulder. J Bone Joint Surg Br 1951;33:180-91.

8. Coester LM, et al. Long-term results following ankle arthrodesis for posttraumatic arthritis. J Bone Joint Surg Am 2001;83:219-28.

9. Dennis DA, et al. Internal compression arthrodesis of the ankle. Clin Orthop 1990;253:212-20.

10. Felix NA, Kitaoka HB. Ankle arthrodesis in patients with rheumatoid arthritis. Clin Orthop 1998;349:58-64.

11. Gatellier J. The juxtaretroperoneal route in the operative treatment of fracture of the malleolus with posterior marginal fragment. Surg Gynecol Obstet 1931;52:67-70.

12. Goldthwait JE. An operation for stiffening of the ankle joint in infantile paralysis. Am J Orthop Surg 1908;5:271-5

13. Hintermann B. Die STAR-Sprunggelenkprothese; kurz- und mittelfristige Ergebnisse. Orthopäde 1999;28:792-803.

14. Holt ES, et al. Ankle arthrodesis using internal screw fixation. Clin Orthop 1991;268:21-8.

15. Horwitz T. The use of the transfibular approach in arthrodesis of the ankle joint. Am J Surg 1942;55:550.

16. Kitaoka HB, et al. Clinical rating systems for the ankle-hindfoot, midfoot, hallux and lesser toes. Foot Ankle Int 1994;15:349-53.

17. Kofoed H. Die Entwicklung der Sprunggelenksarthroplastik. Orthopäde 1999;28:804-11.
18. Kofoed $\mathrm{H}$, Lundberg-Jensen A. Ankle arthroplasty in patients younger and older than 50 years: a prospective series with long-term follow up. Foot Ankle Int 1999;20:501-6.

19. Mann R, et al. Ankle fusion. Clin Orthop 1991;268:49-55

20. Mann R, Rongstad KM. Arthrodesis of the ankle: a critical analysis. Foot Ankle Int 1998;19:3-9.

21. Maurer RC, et al. Transarticular cross-screw fixation. A technique of ankle arthrodesis. Clin Orthop 1991;268:56-64.

22. Moeckel BH, et al. Ankle arthrodesis. A comparison of internal and external fixation. Clin Orthop 1991;268:78-83.

23. Monroe MT, et al. Clinical outcome of arthrodesis of the ankle us ing rigid internal fixation with cancellous screws. Foot Ankle Int 1999;20:227-31.

24. Pyevich MT, et al. Total ankle arthroplasty: a unique design. J Bone Joint Surg Am 1998;80:1410-20.

25. Rhys HT, et al. Current Concepts Review: Ankle arthritis. J Bone Joint Surg Am 2003;85:923-36.

26. Trouillier $\mathrm{H}$, et al. Long-term results after ankle arthrodesis: clinical, radiological, gait analytical aspects. Foot Ankle Int 2002;23:1081-90.

27. Zvijac JE, et al. Analysis of arthroscopically assisted ankle arthrodesis. Arthroscopy 2002;18:70-5.

\section{Korrespondenzanschrift - Address for Correspondence} Dr. Martin Weber

Universitätsklinik und Poliklinik

für Orthopädische Chirurgie

Inselspital

$\mathrm{CH}-3010$ Bern

Telefon (+41/31) 632-2220, Fax -3600

E-Mail: martin.weber@insel.ch 